\title{
F. Springer: diplomaat-skrywer
}

\begin{abstract}
F. Springer, pseudonym of Dutch ex-diplomat Carel Jan Schneider, fills a unique position in the present-day Dutch literary scene in that the action of his prose works is usually not situated in the Netherlands but mostly in exotic places where Schneider was posted to as an employee of the Dutch foreign service. Having Java as his place of birth and Dutch New Guinea as his first place of assignment, quite a few of his earlier stories and short novels focus on the fateful encounter between Western administrative efficiency or approach to colonial life and Eastern (mainly primitive) ways of living. As a sceptic, Springer views the while man's colonial administration as 'futile scribbling in the margins of history'. Springer's main works are the novels Bougainville, noted for its unique structure, and Quissama, a gripping evocation of posicolonial Angola. In these and other of his texts Springer regards writing as a way of making his existence more bearable and keeping misery, encountered in all third world countries, at a distance in order not to be engulfed by it. He also views it as his expression of opposition against the world of make believe and the deception of modern diplomacy and international trade relations.
\end{abstract}

\section{Die buiteland as inspirasiebron}

Agter die naam F. Springer skuil die gewese diplomaat en ambassadeur Carel Jan Schneider. Hy behoort tot 'n groepie Nederlandse skrywers soos F.C. Terborgh, J. van Oudshoorn, H.J. Friedericy, A. Alberts en Marnix Gijsen, wat as diplomate of bestuursamptenare in die buiteland gewerk het. Hulle is ook vir ' $n$ wisselende aantal van hulle literêre geskrifte geïnspireer deur ervarings in vreemde lande. In die geval van Springer is dit veral 'Nederlands-Indië' (die huidige Indonesië) wat 'n groot rol in sy lewe gespeel het. Die rede daarvoor is dat die outeur te Batavië, hoofstad van die ou Nederlandse kolonie, gebore is (15 Jan. 1932), tot 1946 in die land gewoon het en in 1958 as bestuursamptenaar na 'n nog nie onafhanklike deel van Indonesiê, naamlik 'Nieuw-Guinea' (tans Wes-Irian), teruggekeer het. Daar het hy tot 1962 gewerk. 
Die tropiese kolonie (veral die eiland Java) het dus 'n vormende invloed op sy geestelike ontwikkeling gehad en inspirerend gewerk. Dieselfde sou 'n mens van Nederlandse skrywers soos Maria Dermoût, Beb Vuyk of Rob Nieuwenhuys kon sê - skrywers wat die grootste deel van hulle lewe in dié gebied gewoon het. Springer behoort egter tot die jongste van hierdie groep, sodat Beb Vuyk (1969) sy werk bestempel het as die sluitstuk van Nederland se koloniale belletrie. Rob Nieuwenhuys (1973) wy dan ook 'n paar bladsye van sy studie Oost-Indische Spiegel aan Springer, maar dit sou verkeerd wees om hom as skrywer uitsluitlik binne die konteks van tipies Nederlands-Indiese literatuur te hou: eerstens omdat die tempo doeloe-tematiek (die nostalgie oor die verbye tyd en die koloniale lewe) net 'n beperkte rol in sy werk speel en tweedens, omdat 'n aantal van sy latere verhale en romans elders gelokaliseer is, naamlik Den Haag, New York, Bangladesh, Iran en selfs Angola. Deur die wisselende funksies en die standplase van die diplomaat is Springer in staat gestel om die storieruimte van sy verhalende tekste gedurig te verander en, soos die Nederlandse skrywer A. Alberts met wie hy soms vergelyk word (Zuiderent, 1975; De Moor: 1981), 'n nugtere waarnemer van mense te wees waar hy hom ook ter wêreld bevind.

Vanweë sy diplomatieke loopbaan het Springer relatief laat bekendheid verwerf in Nederland. Hy was te min in die land om 'n vertroude figuur in die boekreklame te word. Dit het ook in 1977 duidelik geblyk uit die koerant Vrij Nederland se ondersoek na onderskatte skrywers, waar Springer se naam die meeste genoem is deur bekende mede-outeurs. Dit was des te merkwaardiger aangesien hy in dié stadium al een roman en vier bundels kortverhale en novelles gepubliseer het, wat almal baie positief in die Nederlandse pers geresenseer is. Die groot deurbraak het egter vier jaar later gekom met die verskyning van die roman Bougainville (1981) waarmee hy ook die gesogte F. Bordewijk-prys behaal het. 'n Paar jaar later is sy statuut bevestig met die roman Quissama (1985) wat 'n geruime tyd boaan die lys van die mees gelese Nederlandse boeke gestaan het. Die gevolg was dat die diens vir "Collectieve Propaganda van het Nederlandse Boek" Springer in 1989 gevra het om die sogenaamde Boekenweekgeschenk te skryf - 'n eer wat slegs die bekendste skrywers te beurt val. Dié versoek het gelei tot die publikasie van die kort roman Sterremeer (1990), waarvan nie minder as ' $n$ half miljoen eksemplare gedruk is nie.

Die stof van Springer se werk is hoofsaaklik gebaseer op persoonlike ervarings met mense in 'n groot verskeidenheid plekke wat hy in sy diplomatieke loopbaan leer ken het. Sy motivering om te skryf vind ons al in een van sy eerste verhale, naamlik "Dwars door de Vogelkop", waar hy onder meer sê: "Laat ik de feiten in doodnuchtere letters neerzetten. De zaak van me afschrijven ...". Skryf is dus vir Springer nie bloot 'n goeie storie vertel nie, maar om distansie te neem van 'n sinleë wêreld waar (self)vernietiging aan die orde van die dag is. "Ik heb het 
nodig (...) om afstand te nemen van de ellende om me heen. (...) Om te overleven moet je afstand houden", sê hy in 'n onderhoud met F. Gringhuis (s.a.:4). Die geskrewe woord kan die bestaan draagliker maak deurdat fabulering oor die werklikheid die las daarvan wegneem. Soms is die skryfdaad ook 'n poging om hom te distansieer van, of te verset teen die skynwêreld van diplomasie en die bedrogspul van handel, of, om deur middel van die woord, fabel van werklikheid te skei en albei te bestendig. Dit is waarom aan die einde van Quissama gesê word: "Steeds sneller schreef ik, want alles moest worden vastgelegd voordat er iemand binnenkwam om te beweren dat Pauline, King Velderman en ik zelf nooit hadden bestaan" (p. 159).

Dit val op dat in Springer se vroegste verhale reeds kenmerke en verteltegnieke voorkom wat hy later meermale sal gebruik en verfyn. Die mees opvallende is seker die gebruik van die ek-verteller, uit wie se perspektief gebeurtenisse weergegee word. Die ek-verteller is meestal 'n relativerende waarnemer van menslike strewe, of dit nou sy eie of ander mense s'n is. Dikwels is die waargenome persoon 'n patser, dit wil sê 'n opdringerige, luidrugtige soort mens wat eers sukses behaal, maar ten slotte meestal op tragiese of patetiese wyse aan sy einde kom. In ander gevalle gaan dit om ' $n$ individu wie se lewe op raaiselagtige wyse eindig met sy verdwyning: 'n mens sou hom om dié rede 'n Rimbaud-figuur kon noem. Nog 'n kenmerk, maar dan van suiwer verhaaltegniese aard, is die outeur se tipiese retrogressiewe verteltrant, die spronge vanuit die verhaalhede na die verlede. Springer is 'n meester in die sken "n' ' $n$ verhaalvlegwerk waarin die interaksie tussen verlede en hede subtiel geweef word.

\section{Bericht uit Hollandia (1962)}

Sommige van die genoemde kenmerke kom al voor in Springer se verhaal "Een eskimo op het dak", waarmee hy sy literêre loopbaan begin het en in die titelverhaal van sy eerste bundel, Bericht uit Hollandia (1962). "Dwars door de Vogelkop" uit dieselfde bundel was eintlik 'n meer belowende voorbode van Springer se skrywerskap as die titelverhaal. Veral die geslaagde verwerking van die feniksmotief en die strakker hantering van die tragiese verhaalgebeure deur ' $n$ verteller wat waak teen oortollige elemente, maak hierdie verhaal die beste van die drie in die bundel. Met die spookagtige optrede van De Smedt na sy selfmoord, maak die tipies Oosterse irrasionele element, die Couperusagtige stil krag, sy intrede in Springer se werk.

In "Tocties dood" neem die irrasionele die vorm aan van okkulte magte waaroor Papoea-inboorlinge beskik om mekaar te bedreig of dood te maak. Soos "Bericht uit Hollandia" begin "Toeties dood" ook met 'n hofsaak waar die verteller weer as regter optree. In hierdie geval moet hy ene Iremako verhoor, wat sy bose mag gebruik het om die mans van 'n vrou wat hy wil hê, dood te maak. Dié episode 
verkry 'n goed uitgewerkte parallel in 'n verdere episode waar die skeptiese regter se assesor vertel dat hy ook 'n dogter verloor het deur die bose krag van 'n jaloerse of besete buurman.

Wat hierdie bundel en ander verhale en novelles oor Nieu-Guinea boeiend maak, is die jukstaposisie van twee totaal ekstreme beskawings of wêrelde, waaroor uiters min in die Nederlandse literatuur geskryf is: aan die een kant die Papoeas wat letterlik nog in die Steentydperk lewe en aan die ander kant, die oorbeskaafde Hollandse koloniste wat met ' $n$ sterk besef van tydelikheid en meerderwaardigheid probeer om bietjie gesag uit te oefen en orde te handhaaf. Springer se verhale maak dit ook duidelik dat, ondanks die groot verkil in ontwikkelingspeil, albei beskawings ewe verwoestend is: die Hollanders op ' $n$ meer geraffineerde wyse en as gevolg van dekadensie, die Papoeas op grond van brute wapengeweld of okkulte magte. Hoe dan ook, die teëstander moet uit die weg geruim word. Soos Salman in "Bericht uit Hollandia" probeer om die kontroleur te elimineer, gebruik Rejaan in "Toeties dood" sy duistere magte om Lurraputty se dogtertjie te laat dood gaan. Die verteller is nie net wandelaar of waamemer in hierdie werklikheid nie. Hy is intens betrokke by die gebeure en fungeer as sodanig dan ook as skakel tussen die beskawings. Ook ontpop hy as iemand wat niks wil verdoesel of goedpraat nie. Met hierdie benadering kry sy werk, soos Jan Greshoff in Het Vaderland (1962-08-25) destyds gesê het, 'n seldsame algemeen geldigheid.

\section{Schimmen rond de Parula (1966)}

Springer laat in 1966 die novelle Schimmen rond de Parula verskyn - 'n novelle wat in later uitgawes gewoonlik by die bundel Bericht uit Hollandia gevoeg is, waarskynlik omdat die gebeure van hierdie novelle op 'n eiland gesitueer is wat sterk oorecnkomste vertoon met Nieu-Guinea omstreeks die tyd van onafhanklikheidswording. Die onderwerp is die mislukte poging van die sendeling Gerard Dubba en sy vrou Tessie om in die Zakarvallei, een van die mees afgelee dele van die (fiktiewe) Bloedzuigereiland, aan die trotse Zakari-stam en hulle Dingaanagtige opperhoof Zefo die boodskap van Christus se kruisdood te verkondig. Ondanks Springer se skaars verhulde mengsel van bewondering en skeptisisme ten opsigte van dié soort sendingswerk en die fanatieke geloofsywer, het Schimmen rond de Parula tog een van die mees aangrypende en deerniswekkende verhale geword wat hy geskryf het. Daar is duidelik agting vir hierdie geroepenes wat gekontrasteer word met twee kollegas, Carlo en Marie Burd, wat ter wille van die ondersteunende gemeentes in die moederland vervalste berigte oor die groot aantal bekerings stuur, terwyl allerhande ongeregtighede oogluikend toegelaat word. Gerard se eiehandige pogings om die wildste van al die stamme met sy woord en ontwapenende openhartigheid tot insig te bring, loop egter tragies af wanneer sy vrou hom een oggend, na 'n daelange poging tot bearbei- 
ding, gekruisig in die Papoeadorp aantref. Die verkeerd geïnterpreteerde boodskap van plaasvervangende lyding het sy dood veroorsaak.

Die paar bladsye wat daama volg met die beskrywing van Tessie wat die lyk losmaak van die kruis, dit na die rivier sleep en daarmee op 'n vlot rivieraf vaar tot ' $n$ plek waar sy dit vasbind op die vlot en dit in die waterval afstoot sodat dit verdwyn in 'n gebied "dat nog geen ontdekkingsreiziger had ontdekt", is van die treffendste wat Springer ooit geskryf het. Die vertelstyl word tot op die been gestroop van alle tooi sodat slegs die essensie oorbly, uitstekend geskik om die tog deur die oerlandskap en die eenwording met die oerelemente oor te dra. Pas in hierdie stadium begin die leser die belang en die noodsaak insien van die inleidende paar bladsye van die novelle, wat in ' $n$ ander tyd en ruimte geplaas is, naamlik London na Dubba se dood. Uit 'n gesprek tussen Tessie en Brandsen kan ' $n$ mens aflei dat Tessie eintlik ook in ' $n$ illusiewêreld lewe. Die ironie is dat sy eintlik nes Carlo en Marie die waarheid verdoesel, wat haar dus ook 'n onbetroubare verteller sou maak vir Gerard se lewensverhaal. Dit is die rede waarom die verhaal wat dan volg nie vanuit haar standpunt vertel word nie. Springer skakel tereg oor na 'n personale verteller. Die duidelike suggestie is dat slegs die "ironisch noterende waarnemer en outsider", soos Springer homself noem (in Zuiderend \& Korteweg, 1978:5) daartoe in staat is om tot die waarheid deur te dring en ongewenste legendarisering te voorkom.

\section{De gladde paal van macht (1969)}

Springer se eerste roman, De gladde paal van macht (1969), het as ondertitel "een politieke legende". In 'n sekere sin staan hierdie werk in 'n uitsonderingsposisie in Springer se oeuvre, omdat daar in hierdie roman nie 'n afstandelike diplomaat-skrywer aan die woord is wat 'n reeks feite uit sy ervaringswêreld opdiep nie. Die gebeure is suiwer fiktief, so ook die ruimte waarin dit gesitueer is, naamlik die eilandrepubliek D'Unia ('n vervorming van dunia, die Maleise woord vir wêreld), waarmee van die lokale na die universele vlak gespring word. Die tropiese eiland met sy blanke afstammelinge van Vasco de Gama, van wie sommige nog soos die primitiefste Papoeas lewe, is 'n mikrokosmos, 'n wêreldjie wat spieëlbeeld is van die groot wêreld daarbuite. Die teks word gevolglik 'n soort parabel of exemplum. Dit is interessant om verskillende resensente se tiperings van hierdie roman met mekaar te vergelyk. Hans Warren (Provinciaalse Zeeuse Courant, 1969-10-11) noem dit "een politieke fantasie met een parabel- of legendeachtige inslag"; Kees Fens (De Volkskrant, 1969-10-29) praat van 'n "tragi-komedie" en Rob Nieuwenhuys (1973:456) van "een doeltreffende satire". Clara Eggink (Leidsch Dagblad, 1969-10-24) gebruik ook die term "tragikomedie" en noem dit verder "een goede parodie". Volgens Rico Bulthuis (Haagsche Courant, 1970-05-02), ten slotte, is dit "een politieke persiflage". Die feit dat daar so ' $\mathrm{n}$ verskeidenheid tiperings is, bewys wel dat De gladde paal 
van macht moeilik kategoriseerbaar is. Dit staan ruim twintig jaar na sy verskyning nog steeds in ' $n$ unieke posisie in Springer se werk en die Nederlandse literatuur. 'n Mens sou op ' $n$ tematiese verwantskap met Ward Ruyslinck se De Karakoliërs (1969) en, in sekere sin, George Orwell se Animal Farm (1945) kon wys, maar, in teëstelling met laasgenoemde, is Springer se roman op die werklikheid geskoei, "een grootste gemene deler van historische voorvallen" (Fens in De Volkskrant, 1969-10-18). Die botsing tussen die bekrompe en korrupte Brigadier Ohme met D'Unia se president, Wister Hazeltor, wat lei tot die moord op laasgenoemde, reflekteer enige samelewing se onwilligheid om eie bekrompenheid en dwaasheid te laat plek maak vir nuimheid van insig en wysheid. Die oorspronklike van hierdie uiters vlot geskrewe roman lê in die feit dat dit oor so 'n unieke mengsel van dinge gaan: ' $n$ tropiese eiland met ' $n$ blanke bevolking wat so pas onafhanklik geword het en waarvan sommige mense modern is en ander nog oerprimitief. Nieu-Guinea se pas verworwe onafhanklikheid moes Springer geïnspireer het, maar hy verdoesel dit deur die inheemse bevolking tot blankes te omskep, min of meer soos op die negatief van 'n foto. Die resultaat is 'n soort parodie op die selfstandigwording van ontwikkelende lande. Springer besef dat sy teks "een raar product" (Zuiderent \& Korteweg 1978:6) is, maar dat die produk van goeie kwaliteit is, word deur die meeste kritici bevestig.

Alfred Kossmann (De Gelderlander, 1978-01-13) het een keer skerp opgemerk dat Springer se verhale en romans meer Angelsaksies as Nederlands van allure is. Hy bestempel hulle as "tamelijk cynische, snelle, gave vertellingen waarin, bijna altijd in verre landen, erg veel gebeurt". Hierdie parabel oor die universele uitklim van die gladde magspaal verraai daarby die skerp insig van 'n bestuursamptenaar in gesagsmanipulering. Dit is afwisselend snaaks, satiries en absurd, terwyl die sarkasme frustrasie verraai. Moralisering wat so dikwels hierdie soort tekste ontsier, word gelukkig voorkom.

\section{Zaken overzee (1977)}

Nieu-Guinea wat in De gladde paal van macht tot D'Unia verdoesel is, funksioneer in Springer se verhalebundel Zaken overzee (1977) ook nog as vertelruimte. Dit is ook die geval met ander stede of gebiede uit die Verre Ooste, naamlik Bangkok, Bandung of Penang. Springer se werk is hoofsaaklik op herinnerings gebaseer waardeur hy dit outomaties koppel aan bepaalde bekende leefruimtes. Die outobiografiese gegewens stel hom dan ook in staat om met ironie en 'n sterk gevoel vir relatiwiteit die verbye werklikheid te rekonstrueer.

Dit is byvoorbeeld die geval in die outobiografiese titelverhaal of novelle in "Zaken overzee", waarin die ek-verteller gewoon as Springer bekend staan, sy oorplasing na Nieu-Guinea as bestuursamptenaar by die Ministerie van Zaken Overzee, asook ' $n$ menigte avonture met oorlogsugtige Papoeas beskryf word 
Belangrik is die sterk klemtoon wat hier op die idee van betreklikheid val en op die "futiel gekrabbel in de kantlijn van de beschavingsgeschiedenis der mensheid" (p. 70-71) deur so baie Nederlandse amptenaars wat hulleself so ernstig beskou: vandaar die skeptisisme, sinisme en spot by die verteller. Hierdie verhaal wat die Nederlandse koloniale belletrie afsluit, bied 'n boeiende laaste kykie agter die skerms van koloniale bestuur: droë amptenary, holle geklets en gedrink, dikdoenerij en konfrontasie met geweld vorm almal deel daarvan. 'n Mens kan nogtans saamstem met Kees Fens (Die Volkskrant, 1977-10-29) dat Springer dalk die nuwe tyd van die amptenaar en die eindtyd van die bewind skerper op mekaar kon betrek het. Fens het waarskynlik die model van Albert van der Hoogte se roman Het laatste uur (1953) in gedagte gehad.

Die verhaal "De verovering van Bandung" in dieselfde bundel (Zaken overzee), het ook 'n outobiografiese kern, maar dit is ryker aan verbeelding en nie soseer ' $n$ relaas van gebeurtenisse nie. Op vernuftige wyse word 'n parallel gesuggereer tussen ' $n$ klomp seuns in Nederland wat afkomstig is uit Nederlands-Indië en hulleself met sekere seerowers identifiseer, én 'n groep gerepatrieerde koloniste wat onder leiding van die avonturier Raymond Westerling in Nederland klandestien oefen vir die herowering van die stad Bandung. Albei groepe is eintlik rolspelers en in hulle onderskeie fantasiewêrelde weerspieëlings van mekaar. Die komiese groei hier uit tot die groteske en menslike illusies word meedoënloos gerelativeer.

In "Pink Eldorado", geinspireer deur sy tweejarige verblyf in Bangkok, leef Springer, soos hy in 'n onderhoud beweer het, sy afkeer teen 'n bepaalde tipe mens uit, naamlik die gladde bedrieër of die kapokhaantjie. Dit het hy al in sy eerste verhaal, "Een eskimo op het dak", met die figuur van Beer gedoen. Soos Beer kom Robbie Frederiks in "Pink Eldorado" ook tragies aan sy einde. Sy bedrieglike verkoopstaktieke roep die berugte Boorman uit Willem Elsschot se Kaas (1933) in gedagte. Parallelle tussen Elsschot en Springer word dan ook herhaaldelik deur kritici genoem (o.m. Zuiderent, 1975).

\section{Tabee, New York (1974)}

Na Zaken overzee het Nieu-Guinea nie meer as aksieruimte in Springer se werk gefunksioneer nie. Plekke in die verre Ooste, veral Nederlands-Indië, word egter wel as herinneringsruimte opgeroep. Dit is byvoorbeeld die geval in die kort roman Tabee, New York (1974), waarna die gebeure in New York aanleiding gee tot terugflitse oor die lewe in die voormalige Nederlandse kolonie waar die verteller en die persone wat hy onverwags weer ontmoet, gewoon het. Die jukstaponering van leefwêrelde deur middel van die retrogressiewe verhaaltegniek begin meer en meer die sinjattur word van Springer se vertelstyl. Vanuit die vertelhede (New York gedurende 1973) word gedurig skakels gesmee met die 
verlede (Bandung en die Japannese gevangckampc tydens die oorlog). Ons maak gevolglik met hoofsaaklik drie persone kennis: Rudy, die Nederlandse visekonsul in New York, Dola wat destyds in Bandung Rudy se skoolvriendin was en nou getroud is met ' $n$ ander ou skoolmaat, Menno Spanjer. Laasgenoemde is uit dieselfde hout gesny as Flier de Sombreuil in "Happy Days" en Frederiks in "Pink Eldorado" (Zaken overzee).

Jos Radstake (1987:33) het aangetoon dat Springer met dié soort figure eintlik skatpligtig is aan F. Scott Fitzgerald, wat in sy verhale en veral die roman The Great Gatsby (1925), die tematiek van die crack-up bekend gestel het. Springer het in 'n onderhoud die volgende hieroor gesê: "Thema's als crack-up, het zogenaamde slagen in de society/maatschappij en toch natuurlijk met lege handen eindigen, fascineren mij" (Zuiderent \& Korteweg, 1978:9). Menno Spanjer is inderdaad iemand wat met leë hande eindig: van boelie onder die skoolkinders in Bandung ontwikkel hy tot 'n New Yorkse sakeman, wat uitspattig lewe, sy werk verloor en sy frustrasies afreageer op sy familie tot hy hulle skielik verlaat. Soos Jay en Daisy in The Great Gatsby sal Dola, wat toenadering soek tot haar vroeëre liefde (Rudy) die horlosie probeer terugdraai. 'n Soortgelyke situasie kom ook later in Springer se roman Bougainville (1981) voor, waar Tommie Vaulant en Marleen Dorhuis na vyf en twintig jaar die verlore tyd probeer inhaal. Rudy in Tabee. New York is egter nie in staat om die permanente konsekwensies van die hervonde liefde te aanvaar nie, sodat die geskiedenis homself sal herhaal: soos hy destyds in die Bandungse swembad te lafhartig was om Dola te beskerm teen Menno se getreiter, laat hy haar weer in die steek en sê tabee, dit wil sê tot siens, vir New York.

Wat die leser steeds opval in Springer se tekste is die vinnige tempo van die verhaal, wat tog nie verhinder dat die verteller tot die essensie van situasies deurdring nie. Sy verhale word ook altyd met 'n groot dosis humor, ironie en selfspot vertel. Sommige kritici het egter geen vrede gehad met die feit dat Springer die afstand tussen die tragiese en die komiese so klein maak nie. Sy antwoord daarop tipeer hom: "Ellende biedt vaak openingen voor een geestige of sarcastische benadering. Je schept afstand op een niet-zwaarwichtige manier" (Oosthoek in Nieuwsblad van het Noorden, 1990-03-09). Die woordekonomie en direktheid van styl voorkom ook melodrama of sentimentaliteit. Nog 'n ander stylkenmerk is die slim wyse waarop allerhande vrae beantwoord en leemtes gevul word - vrae wat deur die beperkte ek-perspektief aan die begin van die gebeure ontstaan. Die middel by uitstek om dit te realiseer is die subtiel gehanteerde terugflitstegniek. Anbeek (1989:2) praat in dié verband van Springer se "geraffineerde verteltrant". Wat vertelstrategieè en struktuur betref, kan Tabee, New York die voorloper van die meer komplekse roman Bougainville genoem word. 


\section{Sterremeer (1990)}

Sterremeer (1990), die tweede kort roman wat in Amerika gesitueer is, het Springer in opdrag van die "Stichting Collectieve Propaganda van het Nederlandse boek" geskryf. Parallelle met die vorige New York-roman lê voor die hand: 'n ek-verteller (hierdie slag is hy Nikko, 'n Nederlandse prokureur by 'n Amerikaanse firma); 'n land- en generasiegenoot uit Nederland (Felix Sterremeer, wat skynbaar sukses het in die land wat hy as sy eie aangeneem het) en sy vrou wat aanvanklik in hom glo maar teleurgestel raak; 'n gebeure wat ook gedeeltelik in New York afspeel en gedeeltelik in die tuisland. In teêstelling met Rudy in Tabee. New York is Nikko egter veel afstandeliker: hy is meer waamemer, minder betrokke - 'n gegewe wat hom volgens die resensent Carel Peeters (I'rij Nederland, 1990-03-17) "een niet erg sympathiek verteller" maak. Die ironiserende verteltrant is inderdaad nie heeltemal geskik vir hierdie novelle oor die tragiese aftakeling van 'n verhouding nie. Felix Sterremeer sluit as romankarakter duidelik aan by die tipe Springerpersonasies wat, soos onder meer Menno Spanjer in Tabee, New York, 'n opgeblase idee van hulself en hulle vermoëns het. Nuut in hierdie geval is wel dat die betrokke karakter nou ook iemand anders se ondergang veroorsaak: na haar selfinoordpoging is Robie, Felix se vrou, nie meer in staat om te kommunikeer nie. Die parallel tussen haar eie verhouding met 'n mislukkeling van 'n man en dié van 'n mislukte negentiende-eeuse Duitse digter en sy vrou wat Robie bestudeer, word treffend uitgewerk tot motivering vir Robie se eie selfmoordpoging en die tragiese afloop van haar lewe.

\section{Bougainville (1981)}

Dacca, hoofstad van die jong staat Bangladesh, is een van die plekke waar Springer van 1972-1974 as Nederlandse saakgelastigde gewerk het en waar hy die stof vir die roman Bougainville versamel het. Hierdie roman het in 1981 verskyn en is in 1982 met die F. Bordewijk-prys bekroon.

Bougainville, wat vanweê sy boeiende struktuur en gegewe as Springer se beste roman beskou kan word, het as ondertitel: "Een gedenkschrift". Dié frase is baie belangrik omdat dit op 'n essensiële kenmerk, die retrogressiewe struktuur, van die roman wys. Gedenkskrifte belig belangrike momente uit die verlede en onderstreep hoe die opgeroepte verlede van groot belang is vir begrip van die hede. Dit word gou duidelik dat ons hier nie met 'n enkelvoudige verlede te doen het nie en ook dat Springer van die gebruiklike patroon van een ek-verteller afwyk. Daar word ten minste vier vertellers aan die woord gestel.

Die vernaamste verteller is Bo, 'n Nederlandse saakgelastigde wat in Dacca (Bangladesh) 'n kantoor geopen het. Hy kry besoek van 'n jeugvriend, Toinmie Vaulant, wat 'n hoè diplomatieke pos in die Verenigde Volke se hoofkantoor 
beklee. Tydens 'n uitstappie met 'n Switserse vroulike dokter na 'n afgeleë strand in die buurt, het Tommie egter op onverklaarbare wyse in 'n kalm see verdrink. Dié ongeluk (of selfmoord?) is die tragiese eindpunt van 'n lewe wat vanaf sy begin met Bo s'n verbonde was en wat nou in die res van die romangebcure ontrafel word. Hierdie vertelwyse beteken nie dat die verteller louter retrospektief te werk gaan nie. Gebeurtenisse uit Bo se diplomatieke aktiwiteite in Dacca en bepaalde ervarings tydens vakansies in Nederland word ook vertel.

Die gebeure word aansienlik komplekser wanneer ons bewus word van nog meer vertellers, onder meer ene Johan de Leeuw wat in die kursiewe teks aan die woord kom. Dié gedeeltes is uittreksels uit 'n dagboek wat hy in Malang (Java) in 1934-1938 geskryf het en waarin hy herinneringe oor sy jeugjare in Nederland in 1879 en later weergee. Sy pa was ' $n$ vriend en groot bewonderaar van Multatuli, alias Eduard Douwes Dekker ("Dek") wat soms kom kuier het. Voorlopig vorm dié relaas ' $\mathrm{n}$ los draad in die verhaal.

In ander onderafdelings van die teks konsentreer Bo, die hoofverteller, net op sy verlede in onder meer Malang waar hy opgegroei het en langs die familie Vaulant gewoon het, waarvan die seun Tommie, sy speelmaat was. 'n Sentrale persoon in die Vaulant-gesin was die eksentrieke oupa. Mettertyd besef die leser dat dié rumoerige ou man dieselfde persoon is as die De Leeuw wie se outobiografie in die kursiewe gedeeltes weergegee word: in daardie teks word 'n direk vertelde beeld van hom (vanuit sy eie perspektief) as jong man en rokkejaer gegee, terwyl Bo se terugvlugte na die verlede ' $n$ aanvullende perspektief gee op De Leeuw as 'n ou, nukkerige man wat sy kamer angsvallig teen indringers bewaak.

'n Boeiende aspek van Bougainville is dat ons gou op drie verskillende tydsvlakke beweeg, waarby veelvuldige jaartalaanduidings die leser help om homself te oriënteer: die verhaalhede van Bo in Dacca (1973); die tyd van Bo en Tommie se jeug in Malang wat gedeeltelik ooreenstem met Opa de Leeuw se vertelhede in sy dagboek én laasgenoemde se herskepping van sy eie jeug in Rotterdam. Dié stand van sake word nog interessanter wanneer ons op $\mathrm{p}$. 51 agterkom dat Bo die ou man se dagboek in die hande gekry het. Die deurblaai van die teks lei tot die ontdekking van nóg 'n dagboek, naamlik Tommie s'n. Tommie is dus nog 'n verteller: dit blyk dat hy begin skryf het op die bladsy waar sy oupa opgehou het in sy dagboek en dat hy eintlik net so 'n rustelose gees en 'n dromer soos die oubaas was.

Die romangebeure beweeg dus duidelik tegelykertyd op 'n hele reeks verskillende tydsvlakke wat deur die verskillende vertellers/skrywers aangebied word. Elkeen van hulle trek in sy beskrywing 'n reeks ervarings vanuit die eie verlede deur na die vertelhede. Die nadruk val daarin sterk op 'n nogal geïdealiseerde verlede en 'n ontnugterende konfrontasie met die latere werklikheid. 
Die tydshantering in hierdie roman is dus klaarblyklik die struktuurelement waarop die meeste klem val en wat die sleutel bied tot die ontsluiting van die roman se dieper betekenisse en die wêreldvisie waaruit die werk ontstaan het. Hierdie wêreldvisie impliseer naamlik die idee dat die lewe 'n bestaan vol frustrasies is en nie veel meer is as 'n reeks ontmoetings op die pad na 'n sinlose einddoel nie - 'n lewe waarby een persoon hoogstens tydelik ' $n$ ander se reisgenoot sou kon wees.

Die vraag oor die doel van sy bestaan is iets wat Bo al vroeër besighou: "Is het dan allemaal de moeite waard geweest om te creperen hier in dit gat? Wat breng je thuis van je reizen?"' (p. 71). Dit is vrae wat herhaaldelik weerklink in Springer se werk. Bo besef op die ou end dat dit nie sy hoofrol is om diplomaat te speel nie, maar wel om "het eiland Bougainville op papier te krijgen" (p. 125). Met dié woorde word vir die eerste maal die skrywerskap in die werk van Springer getematiseer. Bo staan in die fiktiewe wêreld nie net bekend as saakgelastigde in Dacca (Bangladesh) nie, maar ook as verhaalskrywer. Skryf is hier 'n poging om afstand te neem ("jezelf bijna weg te relativeren", p. 74), te objektiveer en die verlede vanuit die 'korrekte' perspektiewe te sien. Afgesien daarvan is dit ook 'n besimning oor die problematiek van die skrywende instansie om die ontasbare, die onbereikbare, gekonkretiseer in die eiland Bougainville, in woorde te omskep. Bo, die outeur/verteller, het in die loop van die skryflandeling meer en meer ontdek dat hy eintlik 'n soort dubbelganger, 'n alter ego van Tommie is, en dat laasgenoemde se soektog na Bougainville ("mijn vluchtoord") eweseer sy eie soektog is, wat hy terwille van die oorlede vriend en homself op papier moet kry. Soos Proust is hy ook $A$ la recherche du temps perdu (op soek na die verlore tyd) wat hy slegs kan terugvind in die vorm van 'n persoonlike herskepping, naamlik die romanteks.

Bougainville bied baie intertekstuele aansluitingspunte met Multatuli (Tommie en De Leeuw se dagboeknotas teenoor die pak van Sjaalman in Max Harelast) cii Couperus (I)e stille kracht); met Malraux, Du Perron (Het land van herkomst), Scott Fitzgerald, Ford Madox Ford, Robert Lowell, en andere (vgl. Bekkering, 1984 en Neervoort, 1987). Veral Edgar du Perron se Het land van herkomst, wat self intertekstueel skakel met Max Havelaar, moet hier uitgelig word, omdat dit die prototipe van die Nederlandse koloniale nostalgie-roman is en in 'n sekere sin model was vir Bougainville. Daar is byvoorbeeld ooreenstemming in die gebruik van 'n ek-verteller; die heen en weer beweeg tussen die geidealiseerde jeugwêreld in Indië en die ontnugterende volwassenheid elders, die vriendskap van twee seuns wat alter ego's van mekaar is, soos ook die besinming oor 'n skryfproses wat aan die gang is. Ook A. Zuiderent (1986:7) sien Springer as 'n skrywer wat simpatiseer met die tradisie van Multatuli en Du Perron, omdat hulle soos hy skrywers is "voor wie het onderzoek van eigen en andernnans authenticiteit een belangrijke pijler vormt van het literaire werk". 


\section{Quissama (1985)}

Die ondersoek na die eie en veral ' $n$ ander persoon se outentisiteit staan inderdaad sentraal in Quissama (1985), die roman waartoe Springer geïnspireer is deur sy verblyf in Angola, waar hy van 1979 tot 1982 die Nederlandse ambassadeur was. "Quissama" is die naam van een van die wildtuine in Angola waar ' $n$ gedeelte van die handeling plaasvind. Die aandag gaan egter minder uit na die natuur as na die mens, meer spesifiek ene King Velderman, ' $n$ Nederlander wat in Luanda woon, met wie Charles Enders, 'n sakeman, kennis maak en tydelik sy woning deel. Oor Velderman sê Springer in 'n onderhoud (Gringhuis, s.j.4):

Hij is het type van de verweerde tropenblanke die je in oude koloniën wel vaker tegenkomt. Figuren die het in de normale maatschappij niet zien zitten of buitenbeentjes zijn ... Ze lopen dwars door revoluties heen, zijn soms keihard, soms heel gevoelig, maar de binding met wat er in de rest van de wereld gebeurt, zijn ze volkomen kwijt.

Die vlug in die irrealiteit; wensdenkery wat die realiteit leefbaar moet maak; skyn, rolspel en fiksie is dan ook die essensie of die tematiek waaromheen hierdie roman gebou is. Hierdie vlug in irrealiteit sluit aan by wat Max in "Happy Days" (Zaken overzee) sê: "De enige manier om dit bestaan dragelijk te maken is een leven in een schimmenrijk" (Springer, 1977:161). Die motto van Romain Gary wat die romanteks voorafgaan, is 'n verdere rigtingwyser: "Tu ne peux pas aimer une femme, un homme, sans les avoir d'abord inventés" (jy kan nie ' $n$ vrou of ' $n$ man liefhê sonder dat jy hulle eers versin het nie). Hierdie uitspraak se draagwydte word pas duidelık aan die einde van die roman wanneer die verteller (en dus ook die leser) in die onsekerheid gelaat word of Pauline, die vrou wat Velderman ekstaties liefgehad het, werklik bestaan het of nie. ' $n$ Parallel met die duister Dorbeck-figuur, aan wie se bestaan 'n mens ook twyfel in W.F. Hermans se $D e$ donkere kamer van Damocles (1958) lê voor die hand. In albei gevalle word die gebeure in die romans op los skroewe geplaas en die onvermydelike vraag na wat waar is, ontstaan.

Springer se gebruik van 'n raamvertelling om King Velderman en Pauline se gesamentlike lewe te beskryf, is nóg 'n middel om die onsekerheidsfaktor en ironiese distansie te vergroot: wat meegedeel word, staan op rekening van die vertellende persoon, King, en nie op die ek-verteller, Charles, s'n nie. Wat ons egter ineer en meer agterkom, is dat King ' $n$ soort rolspeler in sy eie verhaal is en dat sy relaas van sy verhouding met Pauline ' $n$ vlug in ' $n$ droomwêreld is. Sodra hy aan die einde daarvan kom, is dit vir hom sinloos om langer voort te lewe, aangesien die geidealıseerde geliefde hom verlaat het. Springer laat dié moment saamval met 'n besoek aan die wildtuin Quissama, waar King die blyplek van 'n trop olifante ken wat hy vir Charles en 'n paar toevallige gaste wil gaan wys. King het egter icts 
anders in gedagte as sy medereisigers: hy wil dit ' $n$ grootse skouspel maak, 'n "show" (p. 141), waar hy tussen die olifante hardloop en hulle verwilder en sodoende slagoffer van sy roekelose daad word. Dit maak hom eintlik die teëhanger van Tommie Vaulant in Bougainville, wat ook uit frustrasie oor die onvervulde, in 'n soort oernatuur aan sy einde kom, sonder dat 'n mens sekerheid het of dit nou oor selfmoord gaan of nie.

'n Ander parallel met Bougainville is die verhouding tussen King en Charles, wat in sommige opsigte aan die relasie tussen Bo en Tommie laat dink, met die verskil dat eersgenoemdes nie jeugvriende was nie. Soos Bo is King ook die motivering vir die skryfdaad. "Alles moet worden vastgelegd", deel Charles mee aan die einde van die "relaas", want hy is bang dat daar dalk iemand kom sê "dat Pauline, King Velderman en ik zelf nooit hadden bestaan" (p. 159). Skryf is dus 'n bevestiging van beleefde realiteit wat ondanks die vlugte in irrealiteit nie van sy outensiteit beroof mag word nie. Selfs die anomalieë en die chaotiese toestande van 'n land wat so pas sy postkoloniale tydperk betree het en in 'n staat van verval verkeer, is te min realiteit om nie deur die bedreiging van die irreële aangetas te word nie. Werklikheid en fantasie moet van mekaar geskei word deur die krag van die geskrewe woord. King se mondelinge relaas is nie daartoe in staat nie. Vir Charles is King se verhaal waarheid wat hy moet neerskryf om nie met leë hande agter te bly nie en ook om meer insig in homself te kry, aangesien hy King as 'n soort tweelingbroer sien (vgl. p. 28 en 45). Charles en King is katalisators van mekaar, maar waar King geen uitweg meer sien nie, het Charles nog sy skryfwerk wat vir hom die laaste vorn van singewing is. Albei mans kom in die oernatuur van Quissama tot dieselfde konklusie sonder om dit vir mekaar te sê: "Is dit nu alles? In een donker gat in Afrika snakken naar nieuwe adem?" (p. 124), wat soortgelyke vrae in Bougainville en sekere van die verhale eggo. Vir King sal daar net die fatale spel met die dood oorbly (sy laaste "show") vir Charles die vasklamp aan die woord wat sy wêreld moet orden. Die ander uiterste, ontvlugting in erotiese uitspattighede (vgl. die karikaturale Jules) word nie ernstig oorweeg nie en geld net as groteske alternatief.

\section{Teheran, een zwanezang (1991)}

Springer se lywigste roman, T'eheran, een zwanezang (1991) is nie so geesdriftig deur die Nederlandse pers ontvang soos Bougainville en Quissama nie, veral omdat daar gevind is dat dit 'n aantal oorbodige passasies bevat en op grond van wydlopigheid nie ' $n$ eenheid vonn nie. As 'n mens die teks bloot as verhaal beoordeel, dan is hierdie persoonlike relaas van Toby Harrison, 'n skrywer van gewilde boeke vol "historische feiten met een fantasierijk lawaaisausje" (p. 9) inderdaad effens oorlaai en onnodig lang. Toby werk vir 'n Londonse uitgewery wat sy gewilde reeks "Illustrated Mirror of History and Culture" uitgee - 'n reeks waarin met feite en fiksie 'n lopie geneem word. Vanweë sy bekendheid en ge- 
wildheid aanvaar hy ' $n$ opdrag van die Persiese Sjah om in Teheran die geromantiseerde biografie van die keiserlike geslag van die Pahlavi's te kom skryf. Hierdie opdrag laat hom in ' $n$ broeines van intrige en onrus beland, omdat Iran op die vooraand van die Islamitiese revolusie staan wat die Ayatolla Khomeini aan bewind bring.

Die essensie van Teheran, een zwanezang is egter nie 'n (afwisselend spannende, snaakse of groteske) reeks beelde van 'n groeiende revolusie nie. Hierdie roman is meer as enigiets anders ' $n$ totale ironisering van skrywerskap en die ekstreemste vorm van self-ironie waaraan Springer homself tot nou toe nog onderwerp het. Die ironiseringsproses is meedoënloos: Toby Harrison, die ek-verteller, kom voor as iemand wat geen illusies omtrent homself het nie. Hy noem homself ' $n$ "handelaar in wind" (p. 344) en weet al te goed dat hy net vir geld skryf. Ook oor sy persoon en sy talent het hy geen illusies nie: hy verberg homself permanent agter 'n skuilnaam en beskou homself bloot as "de schim van Piet Hamming" ( $p$. 115), sy vroeëre werkgewer. Elders praat hy van sy huidige werkgewer, Trevor Bailey, as iemand "die mij eigenlijk uitgevonden heeft" (p. 87) en "mijn schepper en meester" (p. 365). Hy besef ook dat hy vir die skryf van sy roman die model van James Morier navolg, 'n 19de-eeuse Engelse skrywer en diplomaat (soos Springer!), wat in 1824 The Adventures of Hadji Baba of Ispahan geskryf het, en waarin meesterlike analises van die Persiese volksaard voorkom. Hadji Baba is vir Toby ook "mijn leermeester" (p. 215).

Toby skryf sy boek tydens die laaste maande van die Sjah se regering, maar die ironie is dat die manuskrip pas voltooi is wanneer die Shah moet wegvlug tydens die Islamitiese staatsgreep. Die boek is trouens nie wat dit veronderstel is om te wees nie. Hy besef dat dit eerder net 'n "liefdesgedicht" (p. 217) of 'n soort Hooglied is vir Patricia Jahanbari, sy mooi Iranese sekretaresse. Dit is 'n boek wat ook nooit uitgegee word nie, geskryf vir 'n geliefde wat nie saam met hom die land wil ontvlug nie. Selfs sy uitgewer vind die manuskrip nie goed genoeg nie, soos die een oor die Belgiese koning Leopold II waaraan hy ook werk. Hy misluk, net soos die Sjah, wie se eerste boek, Mission for My Country (1961), deur die nuwe Iranese maghebbers verwerp word en wie se tweede boek, Answer to History (1980), volgens Toby ook maar net 'n swanesang is. Slegs die "boek agter Aries boek" (p. 209) bly oor, dit wil sê die een wat ons as lesers voor hande het en wat die relaas van 'n mislukking is. Op die ou end is hierdie "zwanezang", die mees siniese van Springer se werke. Sy ek-verteller sien homself as iemand wat maar net deelneem aan die "feest der verliezers" (p. 245) en wat tydelik meegesleur word deur die illusie van ' $n$ poging tot bestendiging deur middel van die geskrewe woord. In laaste instansie draai alles in hierdie roman om (mislukte) boeke - 'n gegewe wat die verteller ook geen illusies laat omtrent sy eie teks nie. 


\section{Bandoeng-Bandung (1993)}

Springer se jongste werk tot op datum is die novelle Bandoeng-Bandung (1993) wat 'n sekere verwantskap vertoon met die ouer novelle Tabee, New York (1974) waarin die oproep van herinneringe aan die Japannese konsentrasiekampe van die Tweede Wêreldoorlog ook ' $n$ kardinale rol speel. Die hoofpersonasie, Chris Regensberg, is nie 'n diplomaat, soos dit meestal die geval is in Springertekste nie, maar ' $n$ afgetrede Nederlandse politikus wat uitgenooi word om saam met sy vrou Vera, ' $n$ aantal besigheidslui en ' $n$ ambisieuse jonger partygenoot ' $n$ handelsmissie te onderneem na Indonesië, sy geboorteland en die plek van sy tydelike gevangenskap. Die 'hoogtepunt' van die reis word die traumatiese herontmoeting met ' $n$ Indonesiese jeugvriend, Otto (Otje) Blanchet, ' $n$ armoedige taxibestuurder in Bandung, waar hy en Chris grootgeword het.

Soos in Bougainville kom in hierdie novelle ook effektiewe tydvlakwisselings voor, in sommige gevalle aangedui deur tekskursiverings. Hierdie tekskursiverings neem toe in aantal namate Regensberg, tydens die rondritte deur die stad, meer en meer begin onthou van die koloniale 'Bandoeng', soos dit destyds genoem is. Hierdie herinneringe aksentueer nie net die kontras tussen die ou en die nuwe stad nie, maar ook tussen die twee mans (Chris en Otje) waarvan die een 'n suksesvolle loopbaan agter die rug het en die ander nog net soos vroeër voortsukkel. Êrens roep die situasie 'n vae eggo op van Hella Haasse se Oeroeg (1948) met sy eiesoortige konfrontasie tussen Oos en Wes, verpersoonlik in twee mans van verskillende rasse wat vyande geword het nadat hulle as seuns met mekaar bevriend was. In Chris en Otje se geval is daar geen kwessie van vyandigheid nie, wel van verdronge skuldkomplekse by Chris wat as veertienjarige ná die kampervarings en by sy vertrek na Nederland destyds vir Otje belowe het om hom te kom haal of hulp te stuur - iets wat hy nooit gedoen het nie.

Chris se katarsis en die groeiende insig in die relatiwiteit van ambisie het nie al die Nederlandse kritici oortuig nie. Hoewel die roman oor die algemeen positief ontvang is, het sommige resensente Springer ten onregte verwyt dat hy neig na die sentimentele. Springer se vertelstyl is egter te beheers en sy lewensvisie te sinies om emosionaliteit toe te laat. Wat wel gesê kan word, is dat Springer in teëstelling met vroeër nie meer soveel klem op aksie as op wisselende stemmings lê nie. Kossmann (De Gelderlander, 1978-01-13) se definisie van Springerverhale as "snelle vertellingen waarin (...) erg veel gebeurt" is nie meer korrek nie. Bandoeng is ook nie meer die paradyslike Malang van Bougainville nie. Die herontmoeting is eerder ' $n$ uiters pynlike ontnugtering waarmee die hooffiguur in hierdie personale novelle sal moet leer lewe. Chris is ook nie meer 'n skrywer soos so baie van Springer se hoofkarakters/vertellers nie - karakters en vertellers wat almal die vermoe (en die onstuitbare drang) het om die traumatiese ervarings van hulle af weg te skryf. 


\section{Samevatting}

Springer het ' $n$ prominente en tegelyk unieke figuur in die moderne Nederlandse literatuur geword - 'n skrywer wie se werk die laaste jare gereeld to die 'top tien' kategorie van die moderne Nederlandse romanliteratuur behoort. Sy verhale uit die vroeë sestigerjare het verwagtings geskep wat met die latere novelles en ten slotte die romans in vervulling gegaan het. Soos in die geval met F. Scott Fitzgerald, bly die outobiografiese element deurentyd 'n belangrike rol in sy werk speel. Hierdie element verleen aan sy vertelhandeling ongetwyfeld ook 'n groot hoeveelheid outentisiteit. Aan die outobiografiese gegewens word 'n nog meer besondere karakter verleen deur die ironiese grondtoon van hierdie realis se werk, wat soos 'n Elsschot met meedoëlose blik die skyn en leuen van die lewe kan blootlê. Min illusies bly oor, behalwe dié van 'n paradyslike jeugwêreld waarna telkens weer teruggekeer word in sy tekste. Toenemende skeptisisme oor die bestaan, gevoed deur die besef van menslike onvermoë om tot lotsverbetering van die ontaarde of verarmde medemens by te dra, laat sy vertellers meestal wegvlug in tekste wat skanse teen die ontnugterende werklikheid bied.

Een van die mees fassinerende aspekte van Springer se werk is dat sy vertellers wat dikwels sy alter ego is, ons bekendstel met 'n hele verskeidenheid raak gekarakteriseerde personasies in 'n groot aantal eksotiese lokaliteite dwarsdeur die wêreld. Of dit nou Hollandia op die vroeëre Nieu-Guinea is, Bandoeng in Nederlands-Indie, Bangkok, Den Haag, New York, Dacca, Luanda of Teheran: orals sien hy met ' $n$ groot sin vir relatiwiteit mense wat aan illusies vasklamp, die illusies probeer omskep tot werklikheid of aan hulle ten onder gaan. Die (meestal eksotiese) agtergrond word by Springer gewoonlik ook 'n boeiende element van sy teks en op meesterlike wyse gebruik die rapporterende ek dit om unieke en deurgaans uitstekend vertelde verhale te laat ontstaan.

\section{Bibliografie}

Anbeek, T. 1989. F. Springer Bougainville In: Lexicon van literaire werken. Alphen a/d Rijn / Brussel / Groningen : Samson / Wolters-Noordhoff

Bekkering. $H$ 1984 Namen, namen, meer dan namen De literaire sprongen van $F$ Springer Literatuur, 1(3): 156-164, mei-juni.

Bekkering, H \& Van Wijck, F 1990. Bougainville en Quissama van F. Springer. Nijmegen Quine.

Bulthuis, R. 1970. Haagsche Courant, 2 mei

De Moor, W A.M 1981 De Tijd, 13 november

Eggink, C. 1969 Leidsch Daghlad, 24 october

Fens, K. 1969. De Volkskrant, 18 october

Fens, K. 1977. De Volkskram, 29 october

Greshoff, J. 1962 Het Vaderland, 25 augustus 
Gringhuis, H s.j. 'Graag vertel ik kampvuurverhalen' In gesprek met F Springer. Inleiding by Quissama. BulkBoek, 17 (178):3-5.

Kossmann, A. 1978. De Gelderlander, 13 januari.

Neervoort, H. 1987. Een koffer boeken: Springers huiswerk. Bzzlletin, 16 (147):25-32.

Nieuwenhuys, R 1973. Oost-Indische spiegel. Amsterdam: Querido

Oosthoek A. 1990 Nielwsblad van het Noorden, 9 maart.

Peeters, C. 1990. Vrij Nederland, 17 maart.

Radstake, J 1987. De Crack-Up Springer en Scott Fitzgerald. Bzzlletin, 147 (16): 33-39

Springer, F. 1962. Bericht uit Hollandia Amsterdam : Querido

Springer, F. 1966. Schimmen rond de Parula. Amsterdam : Querido.

Springer, F. 1969. De gladde paal van macht Amsterdam : Querido.

Springer, F. 1974. Tabee, New York Amsterdam : Querido.

Springer, F. 1977 Zaken overzee. Amsterdam : Querido

Springer, F 1981. Bougainville. Een gedenkschrifı. Amsterdam : Querido

Springer, F 1985. Quissama Een relaas. Amsterdam: Querido.

Springer, F. 1990. Sterremeer Amsterdam : Querido.

Springer, F. 1991. Teheran, een zwanezang Amsterdam: Querido.

Springer, F. 1993. Bandoeng-Bandung. Amsterdam: Querido.

Vuyk, B. 1969. Het Parool, 25 october.

Warren, H 1969. Provinciaalse Zeewwse Couram, 11 october

Zuiderent, A. 1975. Trouw, 8 maart

Zuiderent, A \& Korteweg, A 1978 In gesprek met F. Springer. Maals/af, 26 (8/9): 1-9, aug.-sept

Zuiderent, A 1986. F Springer. Kritisch Literatmur Lexicon. Alphen a/d Rijn/Brussel/Groningen : Samson /Wolters-Noordhoff.

\section{Universiteit van Natal (Pietermaritzburg)}


